\title{
Design of E-Voting Information System for Website-Based Village Head Elections \\ (Case Study : Cemandi Village, Sedati, Sidoarjo, East Java) \\ Perancangan Sistem Informasi E-Voting Pemilihan Kepala Desa Berbasis Website \\ (Studi Kasus : Desa Cemandi, Sedati, Sidoarjo, Jawa Timur)
}

\author{
Aditya Kurniawan ${ }^{1 *}$, Yulian Findawati ${ }^{2}$ \\ \{161080200294@umsida.ac.id¹,yulianfindawati@umsida.ac.id²\}
}

Program Studi Informatika, Fakultas Sains dan Teknologi, Universitas Muhammadiyah Sidoarjo, Indonesia

\begin{abstract}
Voting in a democratic country is an important part of the means of choosing leaders. The village head election process in Indonesia still uses conventional voting methods, namely using ballot paper media in the election process. Voting that is carried out conventionally has several obstacles, including the lack of guaranteeing the authenticity of voters' votes, so that people think the results of voting results are often manipulated. In addition conventional selection is deemed inaccurate and time-consuming and costly. In this study the aim of this research is to design an information system e-voting that can be used for the Election of the Village Head of Cemandi, Sedati, Sidoarjo, East Java, where by using this system the election process becomes easier by ensuring the accuracy of the vote count. This system development method uses the model of software engineering waterfall. The test results blackbox show that the functions of the features in the system are running well. Based on the UAT test, the system received an average percentage rate of $86 \%$.
\end{abstract}

Keywords - Blackbox testing; E-voting; UAT; Village Head Election; Waterfall

\begin{abstract}
Abstrak. Pengambilan suara dalam suatu negara demokrasi merupakan bagian penting untuk sarana memilih pemimpin. Proses pemilihan kepala desa di Indonesia masih menggunakan metode pemungutan suara konvensional, yaitu menggunakan media kertas suara dalam proses pemilihannya. Pemungutan suara yang dilaksanakan secara konvensional memiliki beberapa kendala, diantaranya kurang menjamin keaslian suara pemilih, sehingga masyarakat menganggap hasil perolehan suara sering dimanipulasi. Selain itu pemilihan secara konvensional dirasa kurang akurat dan cukup memakan banyak waktu dan biaya. Pada penelitian ini bertujuan untuk merancang sistem informasi e-voting yang dapat digunakan untuk Pemilihan Kepala Desa Cemandi, Sedati, Sidoarjo, Jawa Timur, dimana dengan menggunakan sistem ini proses pemilihan menjadi lebih mudah dengan menjamin keakuratan dalam perhitungan suara. Metode pengembangan sistem ini menggunakan rekayasa perangkat lunak model waterfall. Hasil pengujian blackbox menunjukkan bahwa fungsi fitur yang ada dalam sistem sudah berjalan dengan baik. Berdasarkan pengujian UAT, sistem mendapatkan rata-rata presentase $86 \%$.
\end{abstract}

Kata Kunci - Blackbox testing; E-voting; UAT; Pemilihan Kepala Desa; Waterfall

\section{PENDAHULUAN}

Desa sebagai kesatuan masyarakat hukum yang otonom dalam proses perkembangannya akan mengalami penurunan, sebab menjadi sub-sistem dari institusi yang lebih besar dalam piramida kekuasaan termutakhir [1]. Terdapat pada pasal 1 ayat (1) Undang-Undang Republik Indonesia Nomor 6 Tahun 2014 tentang Desa dijelaskan bahwa, "Desa adalah desa dan desa adat atau yang disebut dengan nama lain, selanjutnya disebut desa, adalah kesatuan masyarakat hukum yang memiliki batas wilayah yang berwenang untuk mengatur dan mengurus pemerintahan, kepentingan masyarakat setempat berdasarkan prakarsa masyarakat, hak asal usul, dan/atau hak tradisional yang diakui dan dihormati dalam sistem pemerintahan Negara Kesatuan Republik Indonesia [2].

Kepala Desa adalah pejabat pemerintah desa yang mempunyai wewenang, tugas dan kewajiban untuk menyelenggarakan rumah tangga desanya dan melaksanakan tugas dari pemerintah dan pemerintah daerah. Secara eksplisit Pasal 26 ayat (1) Undang-Undang No. 6 Tahun 2014 mengatur empat tugas utama kepala desa, yaitu: menyelenggarakan pemerintahan desa, melaksanakan pembangunan desa, melaksanakan pembinaan masyarakat desa, dan memberdayakan masyarakat desa [2].

Pemilihan kepala desa merupakan salah satu bentuk dari pembangunan demokrasi politik yang dimulai di tingkat lokal (desa). Berdasarkan Peraturan Pemerintah Republik Indonesia No. 72 Tahun 2005 tentang Desa, menjelaskan bahwa kepala desa dipilih langsung oleh penduduk desa dari calon-calon yang telah memenuhi syarat. Pemilihan 
Procedia of Engineering and Life Science Vol. 1. No. 2 Juni 2021

Seminar Nasional \& Call Paper Fakultas Sains dan Teknologi (SENASAINS $2^{\text {nd }}$ )

Universitas Muhammadiyah Sidoarjo

kepala desa ini bersifat langsung, umum, bebas, rahasia, jujur, dan adil. Pemilihan kepala desa dilaksanakan melalui tahapan pencalonan dan tahapan pemilihan [3].

Selama ini pemilihan kepala desa diselenggarakan dengan cara konvensional atau dengan cara mencoblos. Seiring perkembangan teknologi informasi yang semakin pesat membawa perubahan yang besar bagi manusia, termasuk cara untuk melakukan pemilihan. Penggunaan teknologi pada pelaksanaan pemilihan ini dikenal dengan istilah electronic voting.

Electronic voting merupakan suatu sistem pemilihan dimana data dicatat, disimpan dan diproses dalam bentuk informasi digital [4]. E-voting memiliki makna lain yaitu pemungutan suara yang prosesnya dimulai dari pendaftaran pemilih, pelaksanaan pemilihan, perhitungan suara, dan pengiriman hasil suara [5]. Terdapat beberapa syarat agar sistem $e$-voting dapat dipercaya oleh masyarakat, yaitu: aman/terjamin, akurat, dapat dihitung kembali dan kemudahan untuk mengakses.

Berdasarkan penelitian sebelumnya dengan judul "Rancang Bangun Sistem Informasi E-Voting Berbasis SMS" menjelaskan bahwa admin memasukkan data beserta nomor telepon siswa, kemudian memasukan data calon yang akan dipilih termasuk jenis dan kode pemilihan. Setelah itu admin memberitahukan kepada pemilih/siswa melalui SMS yang berisikan nama, nomor urut calon ketua, kode pemilihan dan cara memilih dengan format SMS yang benar. Untuk melakukan pemilihan digunakan format SMS KodePemiihan\#NoUrut sedangkan untuk mengetahui hasil pemilihan digunakan format SMS Hasil\#KodePemilihan. Data hasil pemilihan akan tersimpan pada database MySQL. Pada penelitian ini terdapat kelemahan karena proses pemilihan harus berdasarkan format, apabila format SMS salah, maka suara menjadi tidak sah [6].

Berdasarkan latar belakang masalah yang telah diuraikan di atas, hal ini mendorong penulis mengajukan proposal skripsi dengan judul "PERANCANGAN SISTEM INFORMASI E-VOTING PEMILIHAN KEPALA DESA BERBASIS WEBSITE (Studi Kasus: Desa Cemandi, Sedati, Sidoarjo, Jawa Timur)". Dengan dilakukannya penelitian tersebut, penulis berharap nantinya akan didapatkan sebuah sistem voting yang melibatkan sumber daya manusia yang sedikit dan mampu menggantikan tempat kertas suara, bilik suara dan kotak suara.

\section{METODE}

\section{A. Tahap dan metode pengumpulan data}

Dalam penelitian ini tahapan dan metode pengumpulan data yang digunakan adalah sebagai berikut: a) Pengamatan di Lapangan (Observasi) : Pengamatan di lapangan ini dilakukan dengan cara melakukan pengamatan langsung ke Desa Cemandi, Sedati, Sidoarjo, Jawa Timur, sehingga peneliti mendapat data yang sesuai dengan keadaan yang sebenarnya. b) Wawancara : Wawancara ini dilakukan dengan cara melakukan wawancara langsung dengan masyarakat dan perangkat Desa Cemandi, Sedati, Sidoarjo, Jawa Timur, sehingga peneliti dapat menggali data, informasi dan kerangka keterangan dari subjek penelitian. c) Studi Literasi : Pengumpulan data ini dilakukan dengan pencarian referensi berupa penelitian terdahulu serta metode-metode yang digunakan dalam penyelesaian kasus, kemudian dengan menghimpun data-data lain sebagai pendukung penelitian yang didapat dari berbagai sumber, seperti: buku, jurnal, ataupun penelitian tertulis lainnya.

\section{B. Model pengembangan sistem}

Konsep yang diterapkan dalam pengembangan e-voting pemilihan Kepala Desa Cemandi adalah dengan menggunakan rekayasa perangkat lunak model waterfall. Rekayasa perangkat lunak ialah sebagai disiplin manajerial dan teknis yang berhubungan dengan penemuan sistematik, produksi dan maintenance sistem perangkat lunak yang berkualitas tinggi, disampaikan pada waktu yang tepat serta memiliki harga yang mahal. Ada enam tahapan dalam model waterfall antara lain: a) System/Information Engineering and Modeling. b) Software Requirements. c) Design. d) Coding. e) Testing/Verification. f) Maintenance [7].

\section{Diagram konteks}

Diagram konteks ini menggambarkan alur data dari sistem secara universal. Diagram konteks di bawah menggambarkan bahwa sistem berkomunikasi dengan dua entitas luar yaitu admin dan pemilih. Pada diagram konteks tersebut menjelaskan bahwa admin memberi input data admin, data pemilih dan data kandidat. Pemilih akan memberikan input data login dan data voting. Pada bagian admin memberi output data berupa info admin, info pemilih, info kandidat dan info hasil suara. Pada bagian pemilih memberikan output data berupa info kandidat dan info hasil suara. Berikut adalah diagram konteks sistem $e$-voting dapat dilihat pada gambar 1. 
Procedia of Engineering and Life Science Vol. 1. No. 2 Juni 2021

Seminar Nasional \& Call Paper Fakultas Sains dan Teknologi (SENASAINS $2^{\text {nd }}$ )

Universitas Muhammadiyah Sidoarjo

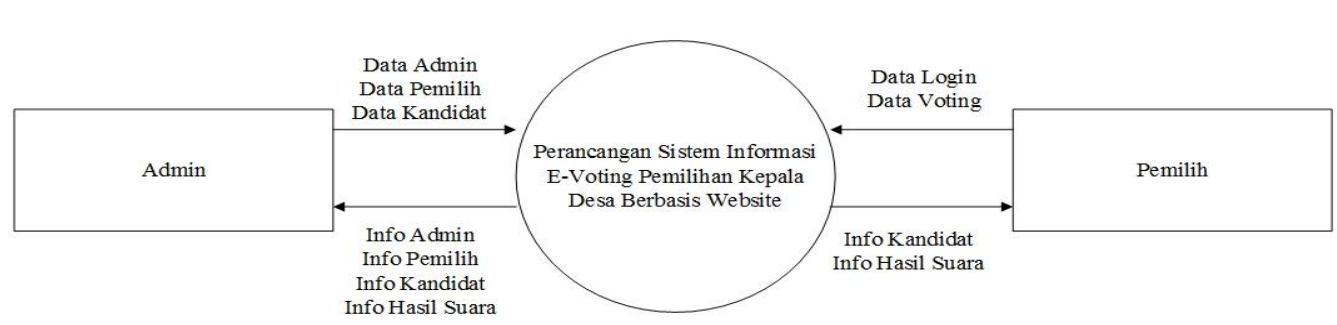

Gambar 1. Diagram Konteks Sistem E-Voting

\section{HASIL DAN PEMBAHASAN}

\section{A. Implementasi sistem}

Implementasi sistem adalah suatu proses untuk menempatkan dan menerapkan informasi baru ke dalam operasi [8]. Implementasi halaman sistem $e$-voting ini dibagi menjadi 3 kategori yaitu: halaman utama (home page), halaman pemilih dan halaman admin.

\section{Proses pendaftaran/verifikasi}

Proses pendafaran/verifikasi pada sistem e-voting pemilihan Kepala Desa Cemandi, Sedati, Sidoarjo masih menggunakan cara konvensional. Admin memberikan surat pemberitahuan pemungutan suara yang berisikan identitas calon pemilih dan tempat pemungutan suara dilaksanakan. Pada proses pendaftaran saat pemilihan, pemilih diwajibkan membawa surat pemberitahuan pemungutan suara untuk dilakukan proses verifikasi oleh admin. Setelah proses verifikasi, pemilih akan diberikan oleh admin username dan password untuk login ke dalam sistem dengan hak akses sebagai pemilih.

\section{Halaman utama (home page)}

Halaman utama (home page) merupakan halaman yang pertama kali ditampilkan saat mengakses sistem. Di halaman tersebut terdapat beberapa menu sistem informasi antara lain: home, quick count, kandidat, voting dan login.

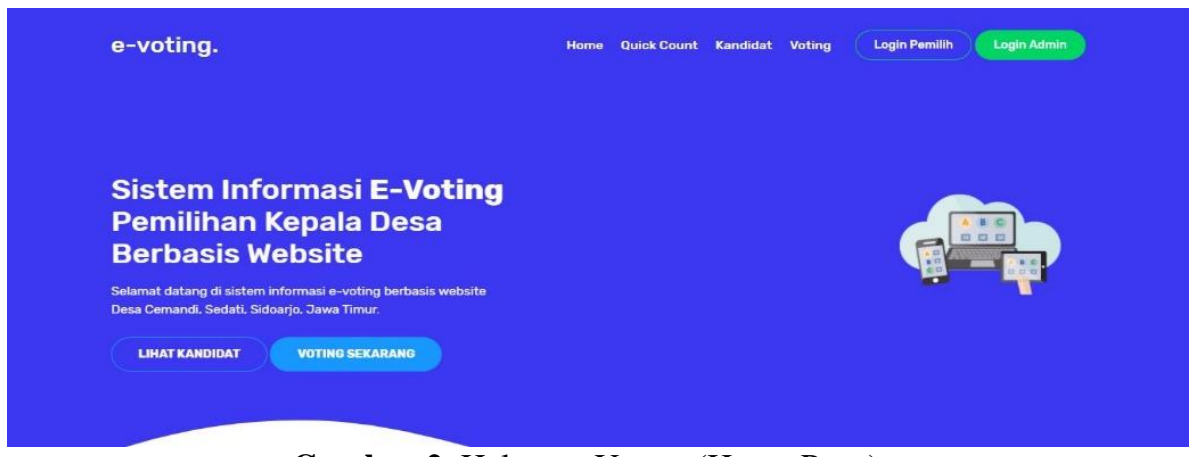

Gambar 2. Halaman Utama (Home Page)

Halaman login pemilih

Halaman login pemilih digunakan untuk login ke dalam sistem dengan hak akses sebagai pemilih. Di halaman tersebut terdapat texfield untuk memasukkan username dan password pemilih.

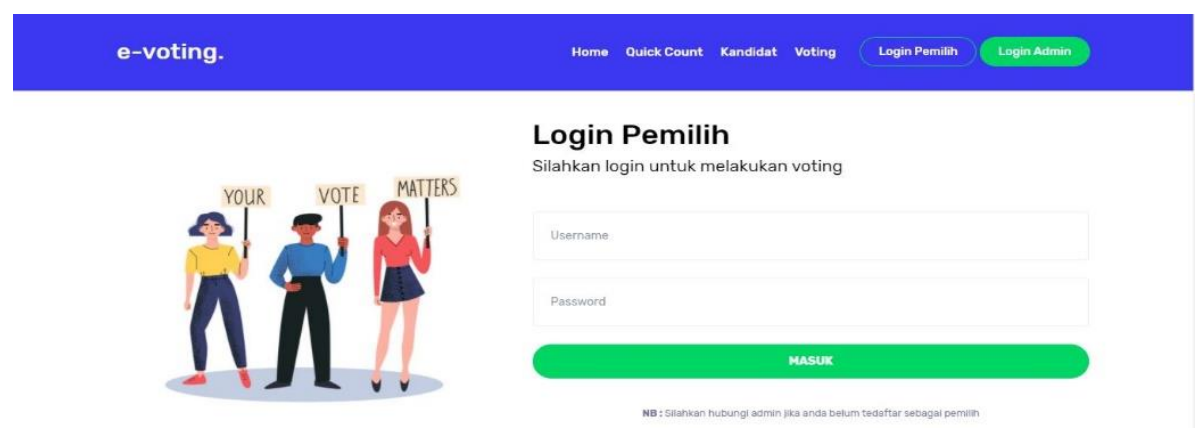

Gambar 3. Halaman Login Pemilih 
Procedia of Engineering and Life Science Vol. 1. No. 2 Juni 2021

Seminar Nasional \& Call Paper Fakultas Sains dan Teknologi (SENASAINS $2^{\text {nd }}$ )

Universitas Muhammadiyah Sidoarjo

Halaman utama pemilih

Halaman utama pemilih merupakan halaman yang pertama kali ditampilkan saat pemilih berhasil login ke dalam sistem. Di halaman tersebut terdapat beberapa menu sistem informasi antara lain: home, quick count, kandidat, voting.

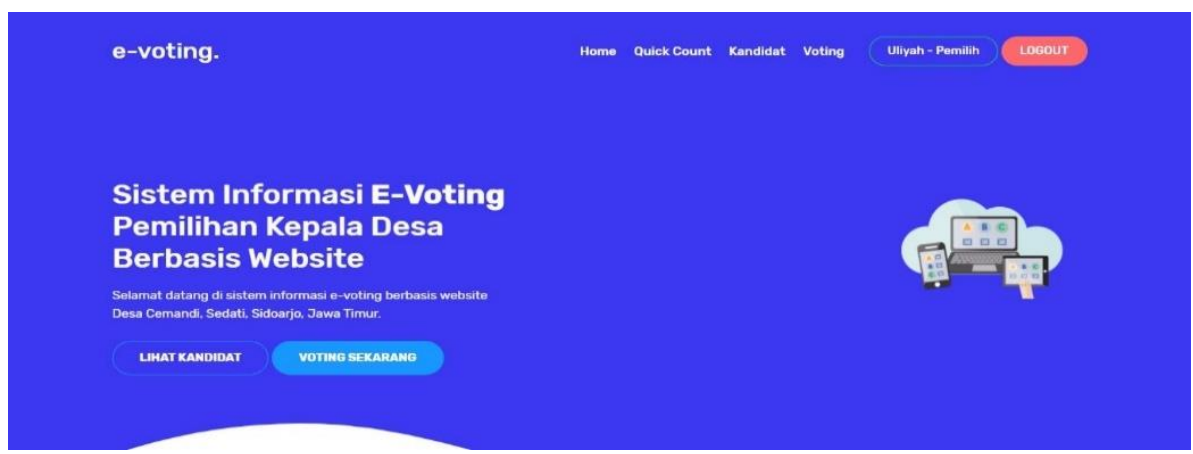

Gambar 4. Halaman Utama Pemilih

Halaman quick count

Halaman quick count digunakan untuk menampilkan hasil presentase perhitungan perolehan suara sementara yang didapatkan dari masing-masing kandidat.

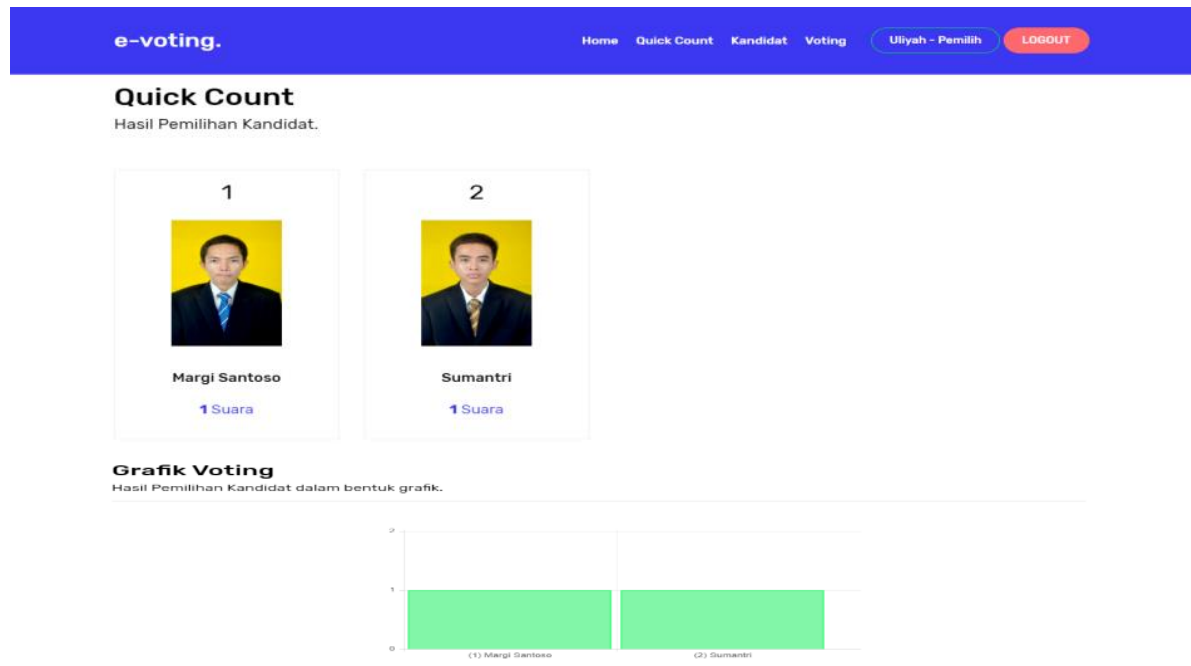

Gambar 5. Halaman Quick Count

Halaman kandidat

Halaman kandidat menampilkan seluruh informasi dari kandidat yang akan dipilih secara detail.

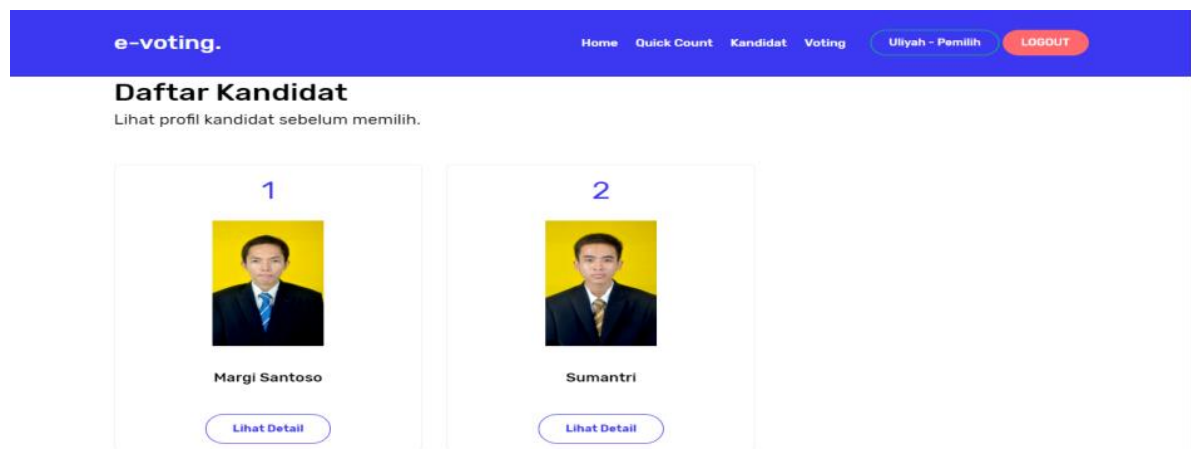

Gambar 6. Halaman Kandidat 
Procedia of Engineering and Life Science Vol. 1. No. 2 Juni 2021

Seminar Nasional \& Call Paper Fakultas Sains dan Teknologi (SENASAINS $2^{\text {nd }}$ )

Universitas Muhammadiyah Sidoarjo

\section{Halaman voting}

Halaman voting digunakan pemilih untuk menyalurkan hak suaranya. Halaman ini dapat diakses jika pemilih yang berhasil login ke dalam sistem dan belum melakukan pemilihan sebelumnya.

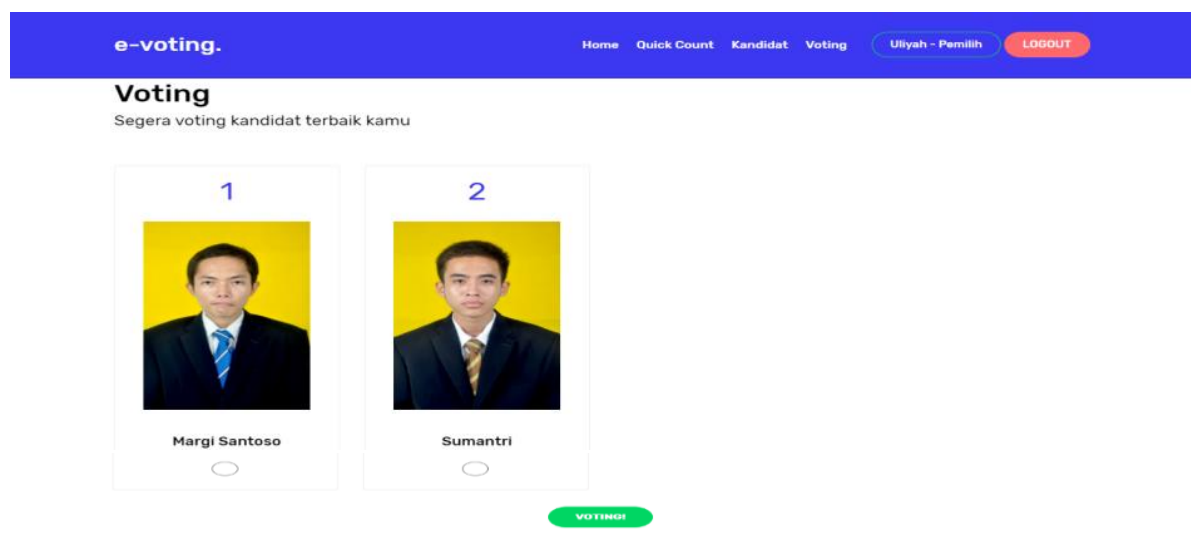

Gambar 7. Halaman Voting

Halaman login admin

Halaman login admin digunakan untuk login ke dalam sistem dengan hak akses sebagai admin. Di halaman tersebut terdapat texfield untuk memasukkan username dan password admin.

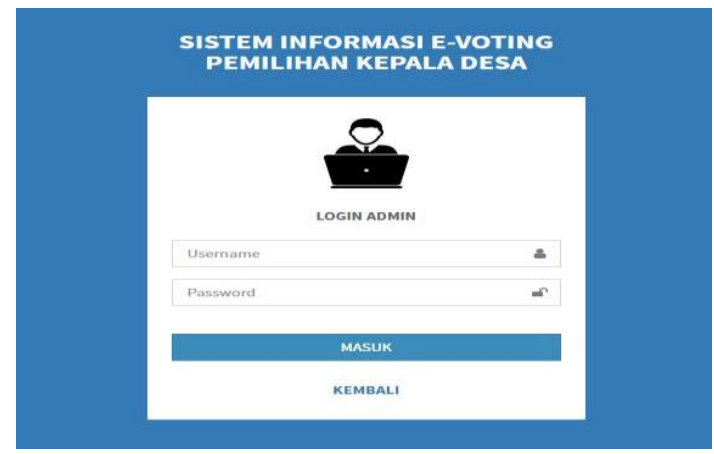

Gambar 8. Halaman Login Admin

\section{Halaman utama admin}

Halaman utama admin merupakan halaman yang pertama kali ditampilkan saat admin berhasil login ke dalam sistem. Di halaman tersebut terdapat beberapa menu sistem informasi antara lain: dashboard, data pemilih, data kandidat, data voting, rekapitulasi voting, data user, ganti password.

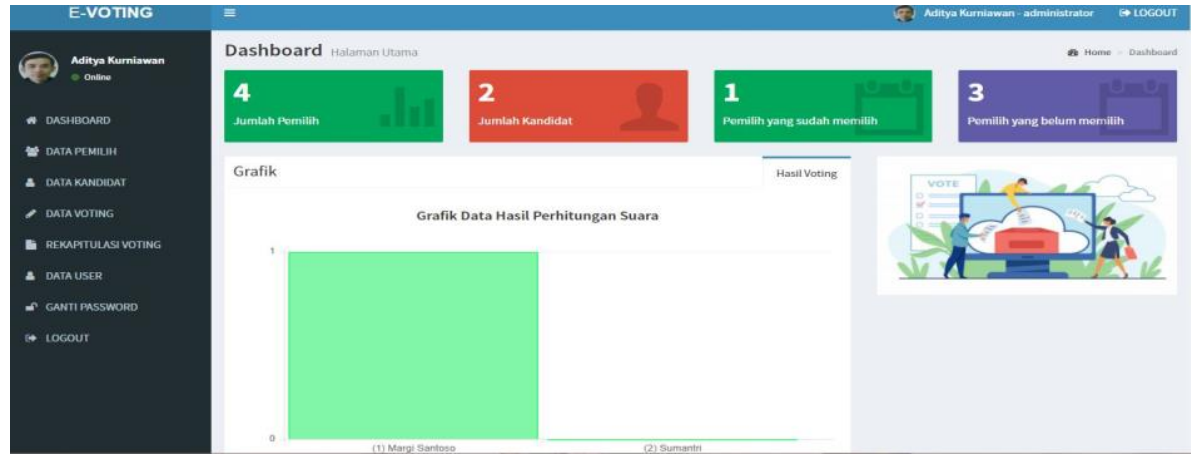

Gambar 9. Halaman Utama Admin

\section{Pengujian sistem}

Setelah dilakukan tahap implementasi, langkah selanjutnya adalah melakukan pengujian pada sistem. Hal ini bertujuan agar hasil akhir sistem yang diimplementasikan sesuai dengan yang dibutuhkan. Peneliti melakukan pengujian sistem $e$-voting ini menggunakan pengujian Blackbox dan pengujian UAT (User Acceptance Test). 
Procedia of Engineering and Life Science Vol. 1. No. 2 Juni 2021

Seminar Nasional \& Call Paper Fakultas Sains dan Teknologi (SENASAINS $2^{\text {nd }}$ )

Universitas Muhammadiyah Sidoarjo

Pengujian blackbox

Blackbox testing disebut sebagai pengujian tingkah laku, memusat pada kebutuhan fungsional perangkat lunak. Teknik pengujian blackbox memungkinkan serangkaian kondisi masukan yang sepenuhnya [9].

Tabel 1. Pengujian Blackbox Halaman Utama (Home Page)

\begin{tabular}{|c|c|c|c|c|}
\hline No & $\begin{array}{c}\text { Requirement } \\
\text { yang diuji }\end{array}$ & Cara pengujian & Hasil yang diharapkan & Keterangan \\
\hline 1 & $\begin{array}{l}\text { Mengakses } \\
\text { Sistem }\end{array}$ & $\begin{array}{l}\text { Mengakses sistem melalui } \\
\text { web browser }\end{array}$ & $\begin{array}{l}\text { Menampilkan halaman utama } \\
\text { (home page) sistem }\end{array}$ & Berhasil \\
\hline \multicolumn{5}{|c|}{ Tabel 2. Pengujian Blackbox Halaman Admin } \\
\hline No & $\begin{array}{l}\text { Requirement } \\
\text { yang diuji }\end{array}$ & Cara pengujian & Hasil yang diharapkan & Keterangan \\
\hline 1 & Login Admin & $\begin{array}{ll}\text { Admin } & \text { memasukkan } \\
\text { username dan password }\end{array}$ & $\begin{array}{l}\text { Admin dapat masuk ke } \\
\text { halaman utama admin }\end{array}$ & Berhasil \\
\hline 2 & Data Pemilih & Klik menu data pemilih & $\begin{array}{l}\text { Admin dapat melihat data } \\
\text { pemilih }\end{array}$ & Berhasil \\
\hline 3 & $\begin{array}{l}\text { Tambah } \\
\text { Pemilih }\end{array}$ & $\begin{array}{l}\text { Klik tombol tambah } \\
\text { pemilih baru }\end{array}$ & $\begin{array}{l}\text { Admin dapat menambahkan } \\
\text { data pemilih baru }\end{array}$ & Berhasil \\
\hline 4 & Edit Pemilih & Klik tombol edit pemilih & $\begin{array}{l}\text { Admin dapat mengedit data } \\
\text { pemilih }\end{array}$ & Berhasil \\
\hline 5 & Hapus Pemilih & Klik tombol hapus pemilih & $\begin{array}{l}\text { Admin dapat menghapus data } \\
\text { pemilih }\end{array}$ & Berhasil \\
\hline 6 & Data Kandidat & Klik menu data kandidat & $\begin{array}{l}\text { Admin dapat melihat data } \\
\text { kandidat }\end{array}$ & Berhasil \\
\hline 7 & $\begin{array}{l}\text { Tambah } \\
\text { Kandidat }\end{array}$ & $\begin{array}{l}\text { Klik tombol tambah } \\
\text { kandidat baru }\end{array}$ & $\begin{array}{l}\text { Admin dapat menambahkan } \\
\text { data kandidat baru }\end{array}$ & Berhasil \\
\hline 8 & Edit Kandidat & Klik tombol edit kandidat & $\begin{array}{l}\text { Admin dapat mengedit data } \\
\text { kandidat }\end{array}$ & Berhasil \\
\hline 9 & $\begin{array}{l}\text { Hapus } \\
\text { Kandidat }\end{array}$ & Klik tombol hapus kandidat & $\begin{array}{l}\text { Admin dapat menghapus data } \\
\text { kandidat }\end{array}$ & Berhasil \\
\hline 10 & Data Voting & Klik menu data voting & $\begin{array}{l}\text { Admin dapat melihat data } \\
\text { voting }\end{array}$ & Berhasil \\
\hline 11 & Print & Klik tombol print & $\begin{array}{l}\text { Admin dapat mencetak data } \\
\text { voting }\end{array}$ & Berhasil \\
\hline 12 & $\begin{array}{l}\text { Rekapitulasi } \\
\text { Voting }\end{array}$ & $\begin{array}{l}\text { Klik menu rekapitulasi } \\
\text { voting }\end{array}$ & $\begin{array}{l}\text { Admin dapat merekapitulasi } \\
\text { voting }\end{array}$ & Berhasil \\
\hline 13 & $\begin{array}{l}\text { Ganti } \\
\text { Password }\end{array}$ & Klik menu ganti password & $\begin{array}{l}\text { Admin dapat mengubah kata } \\
\text { sandi admin }\end{array}$ & Berhasil \\
\hline 14 & Logout & Klik menu logout & $\begin{array}{l}\text { Admin dapat keluar dari } \\
\text { halaman admin }\end{array}$ & Berhasil \\
\hline
\end{tabular}

Tabel 3. Pengujian Blackbox Halaman Pemilih

\begin{tabular}{|c|c|c|c|c|}
\hline No & $\begin{array}{l}\text { Requirement } \\
\text { yang diuji }\end{array}$ & Cara pengujian & Hasil yang diharapkan & Keterangan \\
\hline 1 & Login Pemilih & $\begin{array}{l}\text { Pemilih memasukkan } \\
\text { username dan password }\end{array}$ & $\begin{array}{l}\text { Pemilih dapat masuk ke } \\
\text { halaman utama pemilih }\end{array}$ & Berhasil \\
\hline 2 & Quick Count & Klik menu quick count & $\begin{array}{l}\text { Pemilih dapat melihat quick } \\
\text { count }\end{array}$ & Berhasil \\
\hline 3 & Kandidat & Klik menu kandidat & $\begin{array}{l}\text { Pemilih dapat melihat data } \\
\text { kandidat }\end{array}$ & Berhasil \\
\hline 4 & Voting & Klik menu voting & $\begin{array}{l}\text { Pemilih dapat melakukan } \\
\text { voting }\end{array}$ & Berhasil \\
\hline 5 & Logout & Klik menu logout & $\begin{array}{l}\text { Pemilih dapat keluar dari } \\
\text { halaman pemilih }\end{array}$ & Berhasil \\
\hline
\end{tabular}


Procedia of Engineering and Life Science Vol. 1. No. 2 Juni 2021

Seminar Nasional \& Call Paper Fakultas Sains dan Teknologi (SENASAINS $2^{\text {nd }}$ )

Universitas Muhammadiyah Sidoarjo

Pengujian uat (user acceptance test)

Pengujian UAT (User Acceptance Test) merupakan pengujian yang dilakukan oleh end-user dimana user tersebut adalah staff/karyawan perusahaan yang langsung berinteraksi dengan sistem dan dilakukan verifikasi apakah fungsi yang ada telah berjalan sesuai dengan kebutuhan/fungsinya [10].

Pengujian menggunakan UAT (User Acceptance Test) dilakukan dengan mengajukan beberapa pertanyaan terhadap 15 responden yang terdiri dari, 5 staff/karyawan balai desa dan 10 masyarakat di Desa Cemandi, Sedati, Sidoarjo. Jawaban dari pertanyaan tersebut terdiri dari tingkatan yang dapat dipilih sebagai berikut:

Tabel 4. Bobot Nilai Jawaban

\begin{tabular}{lcc}
\hline \multicolumn{1}{c}{ Jawaban } & Bobot & Presentase \\
\hline A. Sangat Setuju & 5 & $100 \%-80 \%$ \\
B. Sesuai & 4 & $79 \%-60 \%$ \\
C. Kurang Sesuai & 3 & $59 \%-40 \%$ \\
D. Tidak Sesuai & 2 & $39 \%-20 \%$ \\
E. Tidak Jawab & 1 & $19 \%-0 \%$ \\
\hline
\end{tabular}

Hasil data jawaban kusioner akan dihitung presentasenya menggunakan rumus :

Presentase $=\quad$ S $\frac{\times 100 \%}{\text { Skor Ideal }}$

Keterangan :

Presentase $=$ Nilai presentase yang dicari

$\mathrm{S} \quad=$ Jumlah frekuensi dikalikan dengan bobot yang dimiliki tiap jawaban

Skor Ideal $=$ Bobot tertinggi dikalikan dengan jumlah responden

Tabel 5. Skenario Pengujian Kusioner

\begin{tabular}{cl}
\hline No & \multicolumn{1}{c}{ PERTANYAAN } \\
\hline 1 & Apakah tampilan antarmuka sistem e-voting menarik? \\
2 & Apakah anda setuju sebelum masuk ke dalam sistem e-voting harus login terlebih dahulu? \\
3 & $\begin{array}{l}\text { Apakah proses pada menu rekapitulasi e-voting sesuai dengan data pemilih yang telah melakukan } \\
\text { voting sebelumnya }\end{array}$ \\
4 & $\begin{array}{l}\text { Apakah menu quick count membantu dalam mengetahui informasi perolehan suara secara real } \\
\text { time? }\end{array}$ \\
5 & Apakah sistem e-voting dapat mempermudah dalam proses pemilihan? \\
6 & Apakah sistem e-voting dapat menggantikan sistem konvensional? \\
\hline
\end{tabular}

Tabel 6. Data Jawaban Kusioner

\begin{tabular}{|c|c|c|c|c|c|c|c|}
\hline \multirow[t]{2}{*}{ No } & \multicolumn{5}{|c|}{ Frekuensi } & \multirow[t]{2}{*}{$\mathbf{S}$} & \multirow[t]{2}{*}{ Presentase } \\
\hline & $5(A)$ & $4(B)$ & $3(\mathrm{C})$ & 2 (D) & $1(E)$ & & \\
\hline 1 & 7 & 6 & 2 & 0 & 0 & 65 & $86 \%$ \\
\hline 2 & 6 & 8 & 0 & 0 & 1 & 63 & $84 \%$ \\
\hline 3 & 6 & 8 & 1 & 0 & 0 & 65 & $86 \%$ \\
\hline 4 & 6 & 8 & 1 & 0 & 0 & 65 & $86 \%$ \\
\hline 5 & 6 & 8 & 1 & 0 & 0 & 65 & $86 \%$ \\
\hline 6 & 6 & 8 & 1 & 0 & 0 & 65 & $86 \%$ \\
\hline \multicolumn{6}{|c|}{ Total Presentase } & & $86 \%$ \\
\hline
\end{tabular}

Berdasarkan hasil pengujian UAT (User Acceptance Test) di atas, diketahui bahwa dari 15 responden total presentase yang dihasilkan adalah $\mathbf{8 6 \%}$. 
Procedia of Engineering and Life Science Vol. 1. No. 2 Juni 2021

Seminar Nasional \& Call Paper Fakultas Sains dan Teknologi (SENASAINS 2 ${ }^{\text {nd }}$ )

Universitas Muhammadiyah Sidoarjo

\section{KESIMPULAN}

Aplikasi e-voting yang dirancang dapat mengurangi kelemahan terhadap permasalahan pada sistem pemilihan secara konvensional, dan mampu menggantikan tempat kertas suara, bilik suara dan kotak suara. Pemungutan dan penghitungan suara secara elektronik dapat menjamin keaslian suara pemilih, karena suara yang diberikan akan diproses oleh sistem dan tersimpan di dalam database. Setelah melakukan pengujian sistem menggunakan metode Blackbox dan UAT (User Acceptance Test) dapat diambil kesimpulan bahwa sistem dapat diterima dengan baik oleh pengguna.

\section{REFERENSI}

[1] M. Maschab, Politik Pemerintahan Desa di Indonesia. Yogyakarta: PolGov, 2013.

[2] Undang-Undang Nomor 6 Tahun 2014 Tentang Desa.

[3] Peraturan Pemerintah Republik Indonesia Nomor 72 Tahun 2005 Tentang Desa (Lembaran Negara Republik Indonesia Tahun 2005 Nomor 158).

[4] VoteHere, Inc, Network Voting Systems Standards. USA: Public Draft 2, 2002

[5] R. Ali, "Prospek dan Tantangan Penerapan E-Voting di Indonesia," Seminar Nasional Peran Negara dan Masyarakat dalam Pembangunan Demokrasi dan Masyarakat Madani di Indonesia. Jakarta: Universitas Terbuka, 2011.

[6] R.A. Adhi and Hajono, "Rancang Bangun Sistem Informasi E-Voting Berbasis SMS,” JUITA ISSN: 2086-9398 Vol. III Nomor 2, November 2014.

[7] R.S. Pressman, Rekayasa Perangkat Lunak Pendekatan Praktisi (Buku Satu). Yogyakarta: Andi, 2002.

[8] Whitten. jL, L.D. Bentley and V.M. Barrow, System Analysis an Design Instruktur's Edition, Third Edition. Boston: Irwin, 1993

[9] R.S. Pressman, Rekayasa Perangkat Lunak Pendekatan Praktisi, Edisi 7. Yogyakarta: Andi, 2010.

[10] P. William. E, Effective Methods for Software Testing, $3^{\text {rd }}$ Edtion. Indiana, Indianapolis: Wiley Publishing, Inc, 2006. 